\title{
BLUE OCEAN STRATEGY EVALUATION IN GREEN PROPERTY IMPLEMENTATION OF PT. HARMONI PROPERTI INDONESIA
}

\author{
Viviet Yuniastuti
}

STIA Alma Ata Yogyakarta

Email: vivietyun@yahoo.com

\begin{abstract}
Abstrak
Kesadaran masyarakat meningkat dalam pentingnya menjaga planet yang sehat, yang didukung oleh kampanye bumi hijau tanpa henti dari lembaga pemerintah dan non-pemerintah dari dalam dan luar negeri, telah dikirim ke sebuah konsep baru dalam industri properti yang disebut properti hijau. Green property adalah properti yang mempromosikan konsep keberlanjutan dan ramah lingkungan dengan alam sekitarnya, di mana ia akan semakin menjadi kebutuhan bagi pengembangan proyek properti saat ini dan masa depan. Green property tidak hanya pada penanaman hijau, namun juga tentang menjaga efisiensi energi, penanganan limbah, meminimalkan emisi, serta melestarikan eksploitasi sumber daya alam. Fokus pertama dari penelitian ini adalah untuk mencoba membuktikan apakah strategi bisnis yang diterapkan oleh PT. HPI adalah sesuai dengan standar yang benar dari strategi samudra biru, yang didasarkan pada strategi biru laut dibangun Kim \& Mauborgne dalam kitab Blue Ocean Strategy (2005). Mengacu pada metode penelitian sebelumnya yang dilakukan oleh Paramita Ratri (2012), yaitu dengan memanfaatkan 25 poin sebagai indikator dan instrumen dari variabel A (yang merupakan karakteristik dari strategi samudra biru) untuk variabel B (yang merupakan karakteristik dari PT. Strategi HPI) . Evaluasi efektifitas dilakukan dengan mengacu pada tiga perusahaan target inti yang telah menjadi PT. HPI adalah Targetkan Penjualan (TP), Proyek Target Profit (TPP), dan Proyek Berikutnya Target (TPB) dengan pelaksanaan strategi bisnis. 3 (tiga) PT. Target HPI Standar yaitu: Proyek Target Profit (TPP), Target Penjualan (TP), dan Proyek Berikutnya Target (TPB)
\end{abstract}

Kata Kunci: Blue Ocean, Strategi Evaluasi

\section{INTRODUCTION}

Public awareness increasing in the importance of maintaining a healthy planet, which is supported by the relentless green earth campaign from both the government and non-government institutions from inside and outside the country, have delivered to a new concept in the property industry which is called the green property. Green property is a property that promotes sustainability concept and environmentally friendly with natural surroundings, where it would increasingly become a necessity for the current and future property project development. Green property is not only about on planting the green, however it is also about maintaining energy efficiency, 
waste handling, minimize emissions, as well as conserving natural resources exploitation.

On the other hand, from the business point of view, the green property application today can still become an addition to the product value, because there have not been too many manufacturers implementing the concept. Competitiveness of a company could be achieved if the company has successfully formulated and implemented value creating strategies or commonly referred as a value creating strategy (Ireland et al., 2002).

On the other side, the green property application globally has influence on the increased cost ranging from $10-20 \%$. This is due to the existence of several green property criteria which must be accomplished and applied by both the land developer and building materials. According to the Green Building Council Indonesia (GBCI) there are five criteria for green property which are smart design, eco materials, energy efficient, water conservation, and healthy environment. Smart design is a way to maximize the space function in the building in order to reduce the material usage which would then indirectly save energy and costs. Eco material is selecting lightweight building materials, which are recyclable and reusable. Energy efficiency refers to the United States Green Building Council which is being able to reduce energy use by $30 \%$ and the reduction of carbon emissions by $35 \%$, water conservation is the capability of reducing water usage by $30-50 \%$, and healthy environment is being able to reduce waste management costs by $50 \%$. All criteria of green property have certainly increased the costs, and this cost increase has automatically affected on the increase in the selling price to the consumers, therefore the weaknesses of green property is the higher pricing compared to the non-green property.

The condition has become a challenge for developers in creating new solution ideas in order to be able to continue the green property application without being subject any constraints in marketing.

The challenges are also dealt by PT. Harmoni Properti Indonesia, a property development company which officially started their operation since 2005 with the area development including the island of Java, Sumatra, Borneo, Bali, and Nusa Tenggara. PT. Harmoni Properti Indonesia since 2008 has pioneered the concept of green property region development, although has yet been able to execute in total for every developed region. The high priced of green property has remained a challenge for PT. Harmoni Properti Indonesia in finding a strategy for the company in order to maintain the growth while continuing to apply the green property concept. Starting in early 2010, PT. Harmoni Properti Indonesia implemented Blue Ocean strategy by creating innovative products which have not been offered by the property industry, aiming to achieve significant market share with a relatively close to zero (0) competition level for green property in covering the weakness in terms of high price. This is conducted through the launching Holiday Home product. Holiday Home product is a new concept in the property industry, even the term Holiday Home is created by PT. HPI.

Holiday Home is an innovative product which brings together some of home stay concept, villa/guest house, condotel, and apartments functions. Holiday Home is a house in a residential area, which can be utilized as well as a hotel. Consumers are provided a 'value added' of purchasing holiday home, which in addition can be used as a residence and a vacation home, it can also function as a hotel that would provide additional income, in which income can be used to pay the house installments. Contradicting to the villa which

\section{Viviet \\ Yuniastuti}

126

JURNAL EKONOMI SYARIAH INDONESIA, Volume V, No.2 Desember 2015 
is usually a stand-alone building, the holiday home is a building located in the residential areas of housing, therefore, in terms of social relationships, it is very convenient to stay and rest during the holidays. This is also different with apartments and condotel units where the building is located in the hotel building, not in residential areas. As for the hotel management, when occasionally wan to be functioned as a hotel in order to gain more money, the owners do not have to bother because it can be transferred to a third party management with experience in the hospitality industry. The owner is only required to pay the fee for the third party thus the owner can obtain passive income. Supporting the multifunction of Holiday Home, the selected locations should be in the tourist areas of the city. Until recently, Holiday Home has been established in Bali, Lombok, Yogyakarta, and Bandung. Green Property concept has become increasingly supported the main function of home holiday as a tour house. The following is a simulation of consumer's benefit by holiday home product:

Table 1. Consumer's Profit Simulation with Holiday Home Product

Anda tidak akan menyangka kalau hunian semewah ini
\[ \begin{array}{r}\text { seharga Rp. } 200 \text { jutaan } \\ \text { Bahkan bisa gratis }\end{array} \]

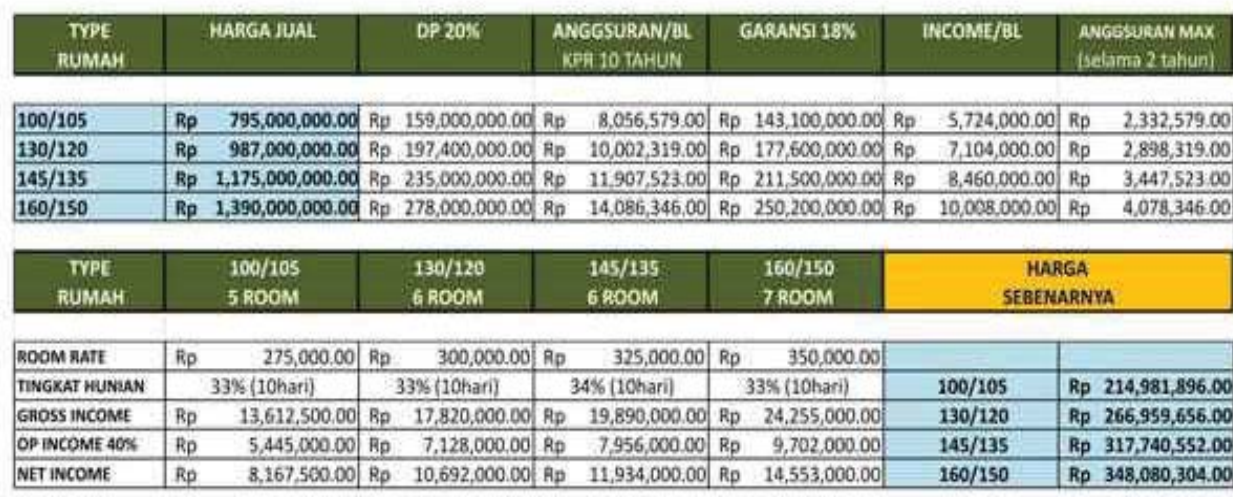

RUMAH GRATIS JIKA TINGKAT HUNIAN MENCAPAI 50\% (SELAMA 65 BULAN)

Source: PT. Harmoni Properti Indonesia (2012)

Green property is a property concept which is designed to be environmentally sustainable, focusing on the efficient use of energy, water and building materials. According to Ji and Plainiotis, (2006) as cited in the book Design for Sustainability, green property is a property concept that refers to accountable structures and processes towards the environment and efficient resource throughout the whole building life cycle, ranging from site to design, construction, operation, maintenance, renovation, and this requires the tight cooperation from teams of the design, architects, engineers, and clients at all stages of the project. Meanwhile according to U.S. Environmental Protection Agency (2009), green property is an extension and complementary of the building design which focuses on economic value, usefulness, durability, and comfort. 
Blue Ocean strategy is a business strategy that seeks to detach from a condition called Red Ocean, which is a condition where the competition to obtain the same market from the competitors is very tight. Industries which is still applying Red Ocean strategy concept will always have to struggle hard for the market share from competitors where the demand is less than the supply. Meanwhile Blue Ocean strategy has an inverse condition compared to the Red Ocean, where competition is close to nothing, because it begins by creating a unique product which has never existed or is different from other existing products. As the products created are new and different from other products, then the market would be interested in the company's products. This has created a bigger demand than supply. According to W. Chan Kim and Renee Mauborgne (Blue Ocean Strategy, 2005), there are four actions in implementation Blue Ocean Strategy. The first is to eliminate, which removes all elements that are not worthy in the product. The second is to reduce, which reduces the elements in which value is small but is still required. The third is to raise (increase), which increases the elements which would become the product benefit over the existing industry standards. The fourth is to create, which creates new things that have never existed in the industry.

As a conclusion, these are difference between Blue Ocean and Red Ocean.

Table 2. Blue Ocean vs Red Ocean

\begin{tabular}{|c|c|}
\hline Blue Ocean Strategy & Red Ocean Strategy \\
\hline $\begin{array}{l}\text { Creating industries that do not exist for } \\
\text { oday - the unknown market space }\end{array}$ & $\begin{array}{l}\text { Enter the industry that already exi } \\
\text { today-the known market space }\end{array}$ \\
\hline & \\
\hline $\begin{array}{l}\text { heir own limits and rules of the } \\
\text { ne }\end{array}$ & $\begin{array}{l}\text { Following restr } \\
\text { game that have }\end{array}$ \\
\hline Create and capture new demand & \\
\hline e-cost & $\begin{array}{l}\text { Cho } \\
\text { cost }\end{array}$ \\
\hline $\begin{array}{l}\text { ntegrate the entire system of the } \\
\text { ompany's activities in pursuit of } \\
\text { lifferentiation and low cost system }\end{array}$ & $\begin{array}{l}\text { Integrate all activities of the company } \\
\text { with the strategic choice of differentiation } \\
\text { or low cost }\end{array}$ \\
\hline novative value $=$ value innovat & Create or add value $=$ additional value \\
\hline
\end{tabular}

Based on the background description above, the problem formulation as the focus of this research is whether or not the strategy adopted by PT. HPI in accordance with the standard blue ocean strategy? and whether the business strategy implemented has been proven to be effective for PT. HPI?

Evaluate the strategy suitability adopted by PT. HPI with blue ocean strategy standard. Analyze the effectiveness of the strategy for PT. HPI

In order to maintain the focus of this research be more focused and keep it in line with the research subject, then the only limitation set for this research is merely to evaluate Blue Ocean strategy application in PT. Harmoni Properti Indonesia for 3 (three) years i.e. from January 2010 to January 2013, which evaluates four Blue Ocean strategy implementation measures which are namely to eliminate, reduce, enhance, and create. As well as on six Blue Ocean principles which is to reconstruct market boundaries, focus on the big picture, explore new demand, conduct the right strategy step, overcome organizational barriers, and build execution processes within the organization.

\author{
Viviet \\ Yuniastuti
}

128

JURNAL EKONOMI SYARIAH INDONESIA, Volume V, No.2 Desember 2015 
Evaluation of this research focuses on proving whether or not business strategies implemented by PT. HPI is in accordance with the Blue Ocean strategy standards, as well as the effectiveness evaluation of the strategy for the company.

\section{Research Method}

\section{Data Type and Source}

There are two types of data required and utilized in this research namely primary data and secondary data.

Primary data is a source of research data which are obtained directly from the original source (not through intermediaries) in the form opinions or thoughts from the research subjects (respondents) individually or as a group, who are gathered to answer research problem (Indriantoro and Supomo, 2009). In this research, primary data are obtained through interviews directly in the form of focus group discussion conducted by the researcher with the five board of directors and top management of the company. According to Nur Indriantoro and Bambang Supomo (2002), interview is a data collection technique in survey method which utilizes questions orally to the subject of the research.

Secondary data is a source of research data which are obtained by finding and collecting materials from library books, previous studies, magazines and journals, as well as other sources which are needed as a reference supporting the research, which is not managed directly by the researcher. In this research, in addition to reviewing books, journals, magazines, online articles, previous studies, the secondary data are also obtained from financial statements and sales reports which are gathered directly from the company studied.

Types of data and data sources are shown in the following Table 3.

Table 3. Research Data Type and Source

\begin{tabular}{ll}
\hline \multicolumn{1}{c}{ DATA } & \multicolumn{1}{c}{ SOURCE } \\
\hline $\begin{array}{l}\text { Primary Data: } \\
\text { - Company Strategy }\end{array}$ & Board of Directors through interview and FGD \\
- Project Profit Target (TPP) & Internal \\
- Sales Target (TP) & \\
- Next Project Target (TPB) & \\
Secondary Data: & \\
- Company vision and mission & Internal \\
- Company Profile & Internal \\
- Journal, books, and article & External \\
- Penelitian sebelumnya & Eksternal \\
\hline
\end{tabular}

\section{Analysis Method}

The first focus of this research is to attempt proving whether business strategies implemented by PT. HPI is in accordance with the true standards of blue ocean strategy, which are based on the blue ocean strategy constructed Kim \& Mauborgne in the book of Blue Ocean Strategy (2005). The proving effort is conducted by identifying the elements possessed by the blue ocean

Blue and of what is conducted by PT. HPI. Referring to previous research method Ocean conducted by Paramita Ratri (2012), namely by utilizing 25 points as the indicators and instruments of variable A (which is the characteristic of blue 129 ocean strategy) to variable B (which is the characteristic of PT. HPI strategy). 
Both of these variables are compared for their compliance where the whole point is taken directly from the book of Blue Ocean Strategy by Kim \& Mauborgne (2005), which are believed to represent characteristics and basic principle of the blue ocean strategy itself (Paramita, 2012). These elements are described in detail to 25 points, where each point has the same score, in order to measure how much similarity possessed by PT. HPI strategy compared to a standard blue ocean strategy. PT. HPI strategy is concluded together with the standard blue ocean strategy with at least $90 \%$ similarity level. This means that if the level of similarity does not reach $90 \%$, it can be concluded that PT. HPI has not applied blue ocean strategy and can simply be categorized as product differentiation strategy (Ratri Paramita, 2012).

Each point has the same value, as follows (Paramita, 2012): The existence of a new concept, Most are established from red ocean, Occurs in market share which is seen by the competitors, Create new demand, Reconstruct market boundaries, Focus on non-customers, Create new market space without competition, Make the competition irrelevant, Form a new competition rules Membentuk aturan persaingan baru, Based on the innovation value, Possess a creative component, Possess focus on one area, Away from other competitors (divergence), Having a compelling main motto, Focusing on the big picture, not the numbers, Perform a series of precise strategic action, Profitable growth opportunities, Characterized by soaring demand for rapid Ditandai dengan permintaan melonjak pesat, The existence of a coherent strategy Adanya strategi koheren, Can run unchallenged Dapat berjalan tanpa tantangan yang berarti, Venture out of the comfort zone, and Fulfilled four steps of the framework: Eliminate, Reduce, Increase, and Create.

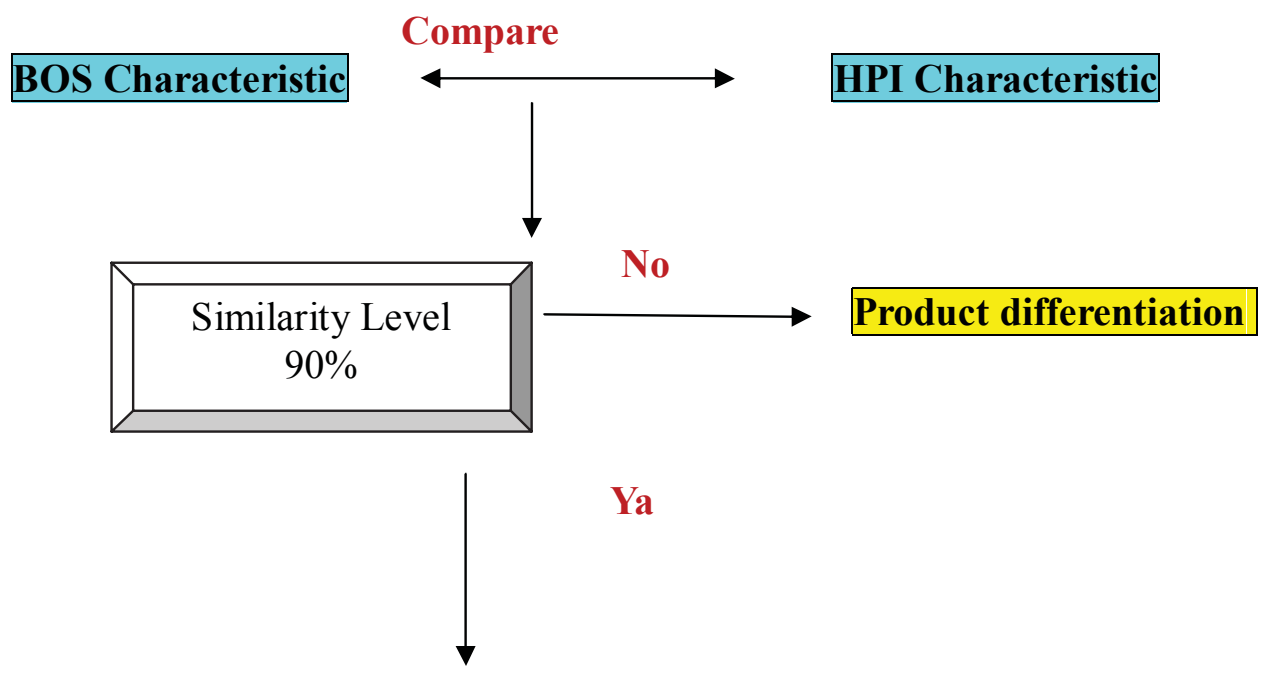

\section{Implementing BOS}

Figure 1 Framework

The focus of future research is to evaluate the business strategies effectiveness of PT. HPI, excluding the evidence on the first research focus results. Effectiveness evaluation is performed by referring to the company's three core targets which have become PT. HPI is Target Sales (TP), Profit Project Target (TPP), and Project Next Target (TPB) with the implementation of the business strategy. The 3 (three) PT. HPI Standard Targets are namely:

\section{Viviet \\ Yuniastuti}

130

JURNAL EKONOMI SYARIAH INDONESIA, Volume V, No.2 Desember 2015 
Profit Project Target (TPP)

Profit Project Target of PT. HPI standard is the net rate of at least $2 x$ of the land project price. When the net benefits of the project does not reach that number, it is considered as not achieving profit target.

Sales Target (TP)

Sales Target at PT. HPI set to be sold out $80 \%$ within a maximum period of 12 months. If the number of units sold is less than the target rate and the time period exceeding sales targets, it is considered that the sales targets are not accomplished.

\section{Next Project Target (TPB)}

Next Project Target is the decision to commence the next project after the current project takes place. In PT. HPI there has been never more than one project at a time. Standards of PT. HPI, the next project would be started after the previous project has been sold out for at least $25 \%$ with a maximum term of six months from the project commencement. If the target for $25 \%$ sold out is achieved in more than six months, then the TPP is not on target. Therefore the faster sales target accomplished, then the sooner next project starts, thus the faster business growth.

The business strategy is considered as effective if it produces the minimal number corresponding to corporate targets, and concluded as ineffective if the result is below the company target.

\section{Research Result}

From the above analysis, it is found that there are 23 points components of A variable corresponding to the $B$ variable. Two points that do not fit is the point number 20 and point number 6 . Therefore from these results, the percentage comparison between PT. HPI strategy with the standard blue ocean strategy is obtained as follows:

$$
23 / 25 \times 100 \%=92 \%
$$

According Ratri Paramita (2012), the percentage above 90\% indicates that the company has implemented blue ocean strategy, therefore the results of $92 \%$ has revealed that the strategy adopted by PT. HPI is indicating the blue ocean strategy.

Table 4. PT. HPI Strategy Fitness Evaluation with Blue Ocean Strategy

\begin{tabular}{|c|c|c|}
\hline BOS Characteristic & HPI Strategy & Score \\
\hline New Concept & $\begin{array}{l}\text { Holiday Home is a new concept in the industry } \\
\text { property }\end{array}$ & 1 \\
\hline Out of Red Ocean & $\begin{array}{l}\text { A result from the long saturated competition in red } \\
\text { ocean }\end{array}$ & 1 \\
\hline $\begin{array}{l}\text { Occurs in market } \\
\text { share which is } \\
\text { not seen by other } \\
\text { competitors }\end{array}$ & There is no competitor who also takes this area & 1 \\
\hline $\begin{array}{l}\text { Creating new } \\
\text { demand }\end{array}$ & $\begin{array}{l}\text { new concept for consumers who want to invest } \\
\text { and own resting places }\end{array}$ & 1 \\
\hline
\end{tabular}

Ocean 


\section{Table 4 (Continued)}

\begin{tabular}{|c|c|c|}
\hline $\begin{array}{l}\text { Reconstructing } \\
\text { market boundaries }\end{array}$ & $\begin{array}{l}\text { Breaking the belief that tourist area is not } \\
\text { prospective and owning a hotel is expensive }\end{array}$ & 1 \\
\hline $\begin{array}{l}\text { Focus on non- } \\
\text { consumers }\end{array}$ & Still focusing on existing consumers & 0 \\
\hline $\begin{array}{l}\text { Creating a new } \\
\text { market without } \\
\text { competition }\end{array}$ & $\begin{array}{l}\text { Holiday home does not have competitors for } \\
\text { similar products. }\end{array}$ & 1 \\
\hline $\begin{array}{l}\text { Make the competition } \\
\text { irrelevant }\end{array}$ & $\begin{array}{l}\text { As there is no competitors, automatically there is } \\
\text { no competition }\end{array}$ & 1 \\
\hline $\begin{array}{l}\text { Establish a new } \\
\text { competition rules }\end{array}$ & $\begin{array}{l}\text { Establish new rules for the competition and } \\
\text { affordable multifunction product }\end{array}$ & 1 \\
\hline $\begin{array}{l}\text { Based on the value } \\
\text { innovation }\end{array}$ & $\begin{array}{l}\text { The innovation offered lies in the concept of } \\
\text { multifunction and investment value accessibility } \\
\text { which are required to be issued by the consumer in } \\
\text { beginning }\end{array}$ & 1 \\
\hline $\begin{array}{l}\text { Having a creative } \\
\text { component }\end{array}$ & $\begin{array}{l}\text { Company principle is "Together We Grow" } \\
\text { therefore involving internal and external creative } \\
\text { component. }\end{array}$ & 1 \\
\hline Focus on one thing & $\begin{array}{l}\text { Focus of PT HPI is on the property and is always } \\
\text { inspired by the company vision }\end{array}$ & 1 \\
\hline $\begin{array}{l}\text { Stay away from } \\
\text { other competitors } \\
\text { (divergence) }\end{array}$ & $\begin{array}{l}\text { Proven to avoid from other competitors even } \\
\text { create new market which has yet to have any } \\
\text { competitors. }\end{array}$ & 1 \\
\hline $\begin{array}{l}\text { Have a compelling } \\
\text { main motto }\end{array}$ & $\begin{array}{l}\text { The motto of home holiday product which attract } \\
\text { consumers is "Buy a House, Free Hotel Plus } \\
\text { Passive Income" }\end{array}$ & 1 \\
\hline $\begin{array}{l}\text { Focusing on the } \\
\text { broad picture, not on } \\
\text { the numbers }\end{array}$ & $\begin{array}{l}\text { Referring to the vision and mission which have } \\
\text { always been used as a business step basis by PT. } \\
\text { HPI, therefore any business product launched does } \\
\text { not only aim financial benefits of the company } \\
\text { alone, but also widens the goal of "growing } \\
\text { together" between companies, clients, and } \\
\text { customers. }\end{array}$ & 1 \\
\hline $\begin{array}{l}\text { Doing the right } \\
\text { strategic sequence }\end{array}$ & $\begin{array}{l}\text { Though lacking of speed, the products launched } \\
\text { are proven to be innovative }\end{array}$ & 1 \\
\hline $\begin{array}{l}\text { The existence of } \\
\text { profitable growth } \\
\text { opportunities }\end{array}$ & $\begin{array}{l}\text { Since the launching achievement above the target } \\
\text { set by the company is obtained }\end{array}$ & 1 \\
\hline $\begin{array}{l}\text { Marked by rapidly } \\
\text { increased demand }\end{array}$ & $\begin{array}{l}\text { The rapidly increase demand only occurs at certain } \\
\text { areas, which is the pure tourist area }\end{array}$ & 1 \\
\hline $\begin{array}{l}\text { The existence of } \\
\text { coherent strategy }\end{array}$ & $\begin{array}{l}\text { Require a relationship and association between } \\
\text { one sector and the other, where each sector cannot } \\
\text { stand up alone }\end{array}$ & 1 \\
\hline $\begin{array}{l}\text { Can operate without } \\
\text { significant challenge } \\
\text { for } 5-15 \text { years }\end{array}$ & Three years old & 0 \\
\hline $\begin{array}{l}\text { Dare to step out of } \\
\text { the comfort zone }\end{array}$ & $\begin{array}{l}\text { Is a product of the red ocean uncomfortable } \\
\text { competition conditions in the green property } \\
\text { industry product }\end{array}$ & 1 \\
\hline
\end{tabular}

Continued

\section{Viviet Yuniastuti}

JURNAL EKONOMI SYARIAH INDONESIA, Volume V, No.2 Desember 2015 
Table 4 (Continued)

\begin{tabular}{|c|c|c|}
\hline $\begin{array}{l}\text { Meet the four steps } \\
\text { of framework } \\
\text { (eliminate) }\end{array}$ & $\begin{array}{l}\text { Removing internal team due to their inexperienced } \\
\text { in holiday home drafting and replace them with an } \\
\text { external team of architects from a third party who } \\
\text { have had experience with the purchasing system } \\
\text { for cost savings }\end{array}$ & 1 \\
\hline $\begin{array}{l}\text { Meet the four steps of } \\
\text { framework (reduce) }\end{array}$ & $\begin{array}{l}\text { Reduce fix marketing staffs to the level of } 50 \% \text { and } \\
\text { hire the rest at freelance as it saves operating costs }\end{array}$ & 1 \\
\hline $\begin{array}{l}\text { Meet the four steps of } \\
\text { framework (increase) }\end{array}$ & $\begin{array}{l}\text { Improving the company's internal human } \\
\text { resources quality by recruiting a team of expert } \\
\text { consultants from cultural / local customs leaders } \\
\text { with the contract system, therefore the holiday } \\
\text { home development would be in line with local } \\
\text { cultures and relatively safe as it recruits local } \\
\text { traditional leaders }\end{array}$ & 1 \\
\hline $\begin{array}{l}\text { Meet the four steps of } \\
\text { framework (create) }\end{array}$ & $\begin{array}{l}\text { New thing that has never been offered by property } \\
\text { industry which should be created is the holiday } \\
\text { home concept itself. }\end{array}$ & 1 \\
\hline Total Score & & 23 \\
\hline
\end{tabular}

The data are by the researcher between the research periods which began from January 2010 until January 2013, it is found that all the projects generate profits above the minimum set by the company, which is at least twice the value of the land. The lowest is $2.11 \times$ the land value and the highest is 2.35 $x$ value of the land. The lowest result is from a project in Senggigi Lombok and the highest is in Bali, however the range difference of each project has just been a little adrift.

\section{Sales Target (TP)}

From the data of Project Sales Report within the period under study which is starting from January 2010 to January 2013, it can be seen that $60 \%$ of all projects managed to achieve above the sales target standard, while the other $40 \%$ is not reached. The achieving sales target are projects in Lombok and Bali, the projects that do not reach the target are projects in Yogyakarta and Bandung. The highest sales target is in Bali where the project achieve sales targets $>80 \%$ in the third month, followed by projects in Lombok who achieve sales target $>80 \%$ in the seventh month. The lowest is in Yogyakarta where the project requires up to twelve months in reaching $37.5 \%$ of the target and in December 2012 reached 50\% sales, slightly above it is a new project in Bandung which achieve sales targets in the fifteenth and sold out in month seventeen.

\section{Next Project Target (TPB)}

Blue

Ocean

The data of Project Sales Report within the period under study which is starting from January 2010 to January 2013, it can be seen that $60 \%$ of the entire project successfully reached the next target project standard above the standard, while the other $40 \%$ is not reached. Projects that achieve Next Project Target are projects in Lombok and Bali, while projects which do not reach 
the target are projects in Yogyakarta and Bandung. The highest achievement is in Bali where the project achieve sales targets $>25 \%$ in the second month, followed by projects in Lombok which achieve sales target $>25 \%$ in six months. The lowest project sales target is in Bandung with $>25 \%$ which has just been achieved in ten months, slightly above it is the new project in Yogyakarta which achieve sales target $>25 \%$ in the eighth month.

\section{RESEARCH RESULT}

\section{Conclusion}

Results of this research find that blue ocean strategy has been embedded and become part of the business practices in PT. HPI.

Results of this research have found that the holiday home concept as a form of the blue ocean strategy practice has proven to be effective to achieve the maximum Profit Project Target (TPP) for the company, however in terms of Sales Target (TP) and Next Project Target (TPB), they are only effective when they are applied at only tourist spots, and are less effective when applied in places aside from the tourist sites, even though it is in the touristic city.

\section{Recommendation}

To keep on using the blue ocean concept with improvements on the one variable which has not been fulfilled namely focus on non customer in trying to widen the strategy towards non-consumers as well.

To focus on development projects only in tourist spots, in order to maximize the achievement of all company's standard target i.e. Project Profit Target (TPP), Sales Target (TP) and Project Next Target (TPB).

It is recommended that the business application with blue ocean concept in PT. HPI does not stop at Holiday Home product, but it also continues to innovate concerning that the product can be easily duplicated by the competitors.

\section{DAFTAR PUSTAKA}

Afuah, A, 2003, Business Model : A Strategic Management Approach, McGrawHill/Irwin, New York.

Baye, M.R., 2009, Managerial Economics and Business Strategy, McGraw-Hill, new York.

Cooper, S, 2008, Business Research Methods, McGraw-Hill/Irwin, New York.

Ferrell, O.C., and G. Hirt, 2008, Business : A Changing World, McGraw-Hill/ Irwin, New York,

Hill, C.W.L., and Jones, G.R, 2001, Strategic Manajemen : An Integrated Approach, Houghton Mifflin, New York.

Indriantoro, N, B. Supomo, 2009, Metode Penelitian Bisnis: Untuk Akuntansi dan. Manajemen, Edisi Pertama, BDFE, Yogyakarta.

Ireland, R. D., Hitt, M. A., Vaidyanath, D, 2002, Alliance Management as a source of Competitive Advantage, Journal of Management.

Ireland, R. D., Hitt, M. A., Vaidyanath, D, 2002, Value Creating Strategy, Journal of Management.

\section{Viviet \\ Yuniastuti}

134

JURNAL EKONOMI SYARIAH INDONESIA, Volume V, No.2 Desember 2015 
Ji, Y, and S. Plainiotis, 2006, Design for Sustainability, Beijing.

Kim, W. Chan, and R. Mauborgne, 2005, Blue Ocean Strategy How to create Uncontested, Harvard Business Press.

Kim, W. Chan, and R. Mauborgne, 2005, Blue Ocean Strategy : Ciptakan Ruang Pasar Tanpa Pesaing dan Biarkan Kompetisi Tak Lagi Relevan, Edisi Indonesia, Harvard Business School Publishing Corporation.

Kotler, P, 2008, Marketing Management: Analysis, Planning, and Control, 11th Edition, Prentice Hall.

Pearce, J. A., II, and R. B. Robinson, Jr., 2009, Formulation, Implementation, and Control of Competitive Strategy, 11th edition, Chicago.

Parvinen, 2011, blue ocean practices: Awareness, action and context-specificity of blue ocean practices in sales management, Emerald Group Publishing Limited.

Pesti, P, 2012, Analisa Persaingan Bisnis Internet Pita Lebar Dengan Pendekatan Blue Ocean Strategy, Study Kasus Layanan Speedy PT. Telekomunikasi Indonesia Area Jabotabek, Tesis FEB, UGM Yogyakarta.

Paramita, R, 2012, Analisa Penerapan Strategi Blue Ocean Pada PT. HM. Sampoerna, Tesis FEB, UGM Yogyakarta.

Prahalad, C.K, 2008, The new age of innovation, Jakarta.

Pitta, D, and Elizabeth P, 2012, Transforming the nature and scope of new product development, Emerald Group Publishing Limited.

Suharsimi, Arikunto, 2006, Prosedur penelitian : suatu pendekatan praktik, Jakarta.

Plus, P, 2010, Strategi Membangun Bisnis Developer Property, Ufuk, Jakarta.

Thompson, A, and J.E. Gamble, 2008, Crafting and Executing Strategy - The Quest for Competitive Advantages, Mcgraw-Hill/Irwin, New York.

http:/ / www.seputar-indonesia.com/edisicetak/content/view/508853/

\section{Blue \\ Ocean}

